\title{
Pengaruh Guided Discovery berbasis Lingkungan terhadap Kemampuan Berpikir Kreatif Siswa SMA
}

\section{The Effects of Environmental Based Guided Discovery toward Students' Creative Thinking Skill}

\author{
RR. PUTRI GELAR NAGRINI ${ }^{\mathbf{*}}$, RIEZKY MAYA PROBOSARI ${ }^{\mathbf{1}}$, JOKO ARIYANTO ${ }^{\mathbf{1}}$ \\ ${ }^{1}$ Pendidikan Biologi, Fakultas Keguruan dan Ilmu Pendidikan, Universitas Sebelas Maret. Jl. Ir. Sutami No.36A, Jebres, Kota Surakarta, \\ Jawa Tengah 57126, Indonesia \\ *Corresponding authors: roroputrigelar@gmail.com
}

Manuscript received: Revision accepted:

\begin{abstract}
The purpose of this study was to determine the effectiveness of Guided Discovery Based on Environment method application toward students' creative thinking skill. This study was a quasi-experimental study using Posttest Only Control Design as a research design. The population in this study was the students of tenth grade in the second semester of SMA N 1 Sukoharjo In The Academic Year 2013/2014. The sampling technique used Cluster Random Sampling. The experiment class is X IPA 1 and the control class is X IPA 2. The data were collected by test and non test. The datas were analysed by t-test. The result of the research showed that the Guided Discovery application method has an effect on students' science process skill. The highest aspect average of creative thinking skill in the experiment class was obtained in fluency aspect that is $95 \%$, while the lowest in originality aspect is $80 \%$. Based on the sequence of the aspects of creative thinking skill from the highest to the lowest. In details, the creative thinking skill was measured by flexibility : $95 \%$, fluency : $87 \%$, elaboration : $82 \%$, originality: $80 \%$. Whereas in the control class, the sequence from the highest to the lowest is flexibility : $93 \%$, fluency : $82 \%$, originality : $69 \%$, elaboration : $65 \%$. The conclusion of this research was Guided Discovery learning method was had significantly affecting the students' creative thinking skill.
\end{abstract}

Keywords: Guided Discovery, Creative Thinking Skill, Environment

\section{PENDAHULUAN}

Biologi sebagai bagian dari sains terdiri dari tiga aspek yang tidak terpisahkan yaitu proses (scientific processes), produk (scientific products) dan sikap ilmiah (scientific attitude). Aspek proses merupakan langkah - langkah siswa dalam seperti observasi, pengamatan, dan analisis data yang telah mereka peroleh. Aspek produk merupakan pemahaman siswa terhadap prinsip-prinsip, hukum-hukum maupun penggunaan rumus dalam ilmu sains. Sedangkan sikap ilmiah merupakan nilai yang terbentuk dalam pembelajaran sains seperti jujur, teliti,tekun, hati- hati, dan bekerja sama. Produk sains dihasilkan melalui penyelidikan ilmiah yang melibatkan sikap ilmiah dan proses sains.

Pembelajaran biologi merupakan wadah mengembangkan kreativitas peserta didik karena pembelajaran biologi bukan hanya penguasaan kumpulankumpulan pengetahuan yang berupa fakta-fakta, konsep atau prinsip-prinsip saja melainkan sekumpulan pengetahuan tentang fenomena dan objek yang di dapatkan dari pemikiran, penyelidikan memalui eksperimen dengan menggunakan model ilmiah.

Pembelajaran biologi dalam pendidikan formal saat ini cenderung terorientasi pada produk. Hal ini terlihat pada peserta didik yang pasif dan hanya mendengarkan penjelasan guru, membayangkan materi yang diajarkan serta mempelajarinya secara textual berdasarkan buku yang ia miliki tanpa mempelajarinya secara real atau nyata dan kurang berinteraksi dengan lingkungan yang ada di sekitarnya. Padahal pembelajaran biologi dapat dialami dalam kehiduan sehari-hari, kapanpun dan dimanapun seseorang dapat menjumpai fenomena biologi termasuk lingkungan dimana ia tinggal. Pembelajaran saat ini cenderung memberi kesempatan siswa untuk menyampaikan gagasan-gagasan dalam menyampaikan pendapat danmenyelesaikan masalah dengan cara mereka sendiri. Akibatnya pembelajaran hanya menekankan produknya saja. Aspek proses dan sikap seringkali diabaikan pembelajaran seperti ini belum melatih siswa untuk berpikir kreatif menemukan konsepnya sendiri. Oleh karena itu para siswa hanya berkutat pada mengasah aspek mengingat dan memahami yang merupakan low order thingking. Hal ini tentunya perlu mendapat perhatian, karena pembelajaran yang demikian dapat menyebabkan kurang berkembangnya kreativitas siswa padahal di era teknologi informasi yang berkembang dengan sangat pesat saat ini, high order thingking menjadi isu penting.

Pembelajaran biologi seharusnya membawa siswa pada taraf belajar yang bukan hanya mengingat. Badan Pendidikan (BSNP) tahun 2006 yang merekomendasikan bahwa dalam pembelajaran perlu tercipta suasana yang aktif, kritis, analisis dan kreatif dalam pemecahan masalah. 
Kreativitas pada intinya kemampuan untuk mengidentifikasi sesuatu yang salah, membentuk ide atau hipotesis mengenai sesuatu tersebut, menguji hipotesis, dan mengkomunikasikan hasil, dalam bentuk memodifikasi atau pengujian ulang hipotesis. Aspek berpikir kreatif meliputi berpikir lancar (fluency), berpikir luwes (flexibility), berpikir orisinil (originality), berpikir terperinci (elaboration).

Kreativitas atau berpikir kreatif sangatlah penting sebagi kemampuan untuk melihat macam-macam kemungkinan penyelesaikan masalah terutama dalam pembelajaran biologi. Peserta didik dibiasakan menggunakan perilaku ilmuwan dalam menemukan konsep yang dilakukan melalui percobaan dan penelitian ilmiah. Namun dalam pelaksaanaan pembelajaran hal ini masih kurang mendapat perhatian. Data Global Creativity Index tahun 2013 menunjukkan Indonesia menempati peringkat 81 dari 82 negara. Posisi ini yang patut dijadikan cermin atau renungan bersama. Untuk memupuk kreativitas dan melatih kemampuan berpikir kreatif siswa, diperlukan suatu metodologi pembelajaran yang sesuai.

Salah satu model pembelajaran yang bisa digunakan untuk mengukur kemampuan berpikir kreatif ialah penemuan (Discovery). Discovery learning merupakan model pembelajaran yang mengatur pengajaran sedemikian rupa sehingga memperoleh pengetahuan yang belum diketahuinya melalui penemuan sendiri. Terdapat beberapa macam Discovery antara lain yaitu free discovery dan guided discovery. Perbedaan keduanya terlihat pada prosesnya saja yaitu model pembelajaran free discovery merupakan penemuan bebas tanpa adanya arahan dari guru kepada siswa. Sedangkan Guided Discovery siswa mendapat arahan dan petunjuk dari guru. Dewasa ini masih ditemui cara mengajar guru yang seolah-olah memberikan semacam resep yang harus diikuti siswa dan masih belum menggunakan Guided Discovery. Selanjutnya dalam pelaksanaannya Guided Discovery cocok digunakan pada sekolah karena siswa masih butuh bimbingan dari guru agar lebih terarah dalam rangka mencapai tujuan yang ingin dicapai.

Guided Discovery dapat meningkatkan kemampuan berpikir kreatif siswa karena memiliki tahapan yaitu stimulation yang mengacu pada aspek berpikir kreatif seperti berpikir luwes (flexibility) melalui rangsangan pertanyaan. Selanjutnya pada tahap data collection yang berkaitan dengan aspek berpikir memperinci (elaboration) melalui kegiatan eksperimen.

Model pembelajaran akan lebih maksimal jika menggunakan sumber belajar yang tepat. Sumber belajar merupakan sarana atau alat terjadinya proses belajar mengajar. Guided Discovery akan lebih mengena jika menggunakan sumber belajar lingkungan. Selama ini guru memang belum mengoptimalkan berbagai sumber belajar yang bermakna, sumber belajar yang digunakan hanya mengacu pada buku saja. Padahal ada sumber belajar yang mudah dijumpai bahkan ada di mana-mana, murah, dan nyata.sumber belajar tersebut salah satunya adalah lingkungan sekitar.
Lingkungan sebagai sumber belajar diharapkan para peserta didik dapat lebih memahami materi pelajaran biologi serta dapat menumbuhkan cinta alam, kesadaran untuk menjaga dan memelihara lingkungan, turut serta dalam menanggulangi permasalahan yang banyak terjadi di lingkungan seperti kerusakan dan pencemaran lingkungan serta tetap menjaga kelestarian kemampuan sumber daya alam bagi kehidupan manusia.

Penelitian ini dilakukan untuk mengetahui pengaruh Guided Discovery berbasis lingkungan terhadap kemampuan berpikir kreatif siswa kelas X SMA Negeri 1 Sukoharjo tahun pelajaran 2013/2014

\section{METODE PENELITIAN}

Penelitian akan dilaksanakan di SMA Negeri 1 Sukoharjo Kelas X tahun pelajaran 2013/2014. Penelitian ini merupakan metode penelitian kuantitatif yaitu pendekatan semu (Quasi Experimental). Disain penelitian menggunakan penelitian Posttest Only With Nonequivalent Control Group Design dimana kelompok eksperimen menggunakan model Guided Discovery berbasis lingkungan dan kelompok kontrol menggunakan model konvensional yaitu ceramah,diskusi dan presentasi.

Populasi dalam penelitian ini adalah seluruh siswa kelas X IPA SMA Negeri 1 Sukoharjo tahun pelajaran 2013/2014 yang terdiri dari enam kelas. Teknik yang digunakan dalam penelitian ini adalah sampling klaster (cluster sampling). Sampel yang diambil adalah kelas $\mathrm{X}$ IPA 1 sebagai kelas eksperimen dan kelas X IPA 2 sebagaikelas kontrol.

Varibel bebas berubah Guided Discovery berbasis lingkungan, variabel terikat adalah kemampuan berpikir kreatif biologi siswa. Metode pengumpulan data menggunakan metode tes untuk mengukur kemampuan berpikir kreatif biologi siswa, dokumentasi untuk mengetahui kesetaraan sampel selama berlangsungnya penelitian, dan observasi untuk keterlaksanaan sintaks. Uji validasi ini menggunakan validasi yang dilakukan oleh ahli meliputi validasi isi dan validasi konstruk.

Analisis data pada penelitian manggunakan uji $t$ independen. Data diperoleh berupa data post test. Sebelum dilakukan uji tindependen perlu dilakukan uji prasayarat yaitu uji normalitas dan uji Kolmogorov-Smirnov dengan koreksi Lilliefors dan uji homogenitas dengan uji Leven's.

\section{HASIL DAN PEMBAHASAN}

Hasil penelitian menunjukan bahwa terdapat pengaruh model Guided Discovery berbasis lingkungan terhadap kemampuan berpikir kreatif biologi siswa kelas $\mathrm{X}$ IPA SMA N 1 Sukoharjo tahun pelajaran 2013/2014. Hasil uji hipotesis pengaruh model Guided Discovery berbasis lingkungan terhadap kemampuan berpikir kreatif biologi siswa disajikan dalam Tabel 1. 
Tabel 1. Hasil uji t

\begin{tabular}{cccc}
\hline Variabel & df & Sig. & Keputusan Uji \\
\hline $\begin{array}{c}\text { Kemampuan } \\
\text { Berpikir } \\
\text { Kreatif }\end{array}$ & 70 & 0,00 & $\begin{array}{c}\text { Ho Ditolak, H1 } \\
\text { diterima }\end{array}$ \\
\hline
\end{tabular}

Tabel 1 menunjukan ada perbedaan yang signifikan rata-rata nilai kemampuan berpikir kreatif biologi siswa antara kelas kontrol dengan model konvensional dan kelas eksperimen dengan model Guided Discovery berbasis lingkungan berpengaruh terhadap kemampuan berpikir kreatif biologi siswa. nilai rata-rata tiap aspek kemampuan berpikir kreatif biologi siswa dapat dilihat pada Gambar 1 .

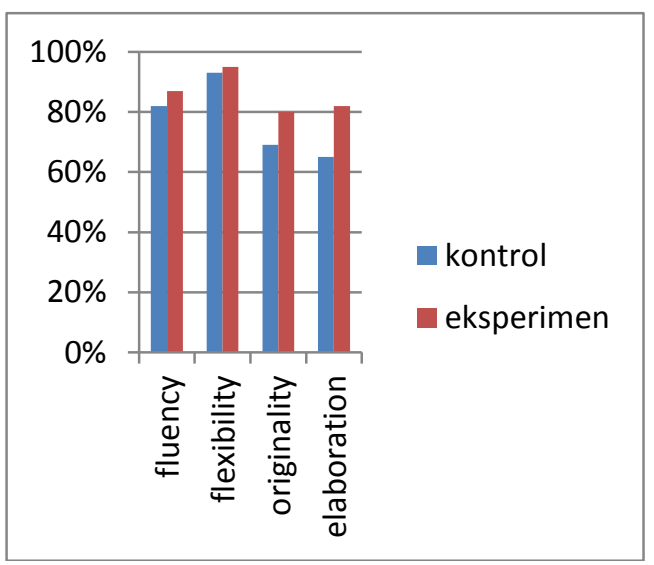

Gambar 1. Presentase nilai rata-rata tiap aspek kemampuan berpikir kreatif

Data diatas menunjukan bahwa presentase nilai rat-rata kemampuan berpikir kreatif tiap aspek pada kelas eksperimen lebih tinggi dibandingkan kemampuan berpikir kreatif pada kelas kontrol yaitu pada kelas eksperimen aspek fluency sebesar $87 \%$, aspek flexibility sebesar $95 \%$, originality sebesar $80 \%$ dan elaboration sebesar $82 \%$ sedangkan pada kelas kontrol yaitu aspek fluency sebesar $82 \%$, aspek flexibility sebesar $93 \%$, originality sebesar $69 \%$ dan elaboration sebesar $65 \%$.

Berdasarkan observasi keterlaksanaan sintaks, model pembelajaran Guided Discovery berbasis lingkungan berjalan dengan baik.

Pada pertemuan pertama siswa dilatih kemampuan berpikir kreatifnya melalui tahap stimulation yang mengoptimalkan aspek berpikir kreatif flexibility melalui kegiatan di pertemuan pertama yaitu guru memberikan rangsangan kepada siswa melalui gambar pencemaran lingkungan pada LKS dan menunjukan dua botol masing masing berisi air yang tercemar limbah dan air bersih. Siswa terlihat penasaran dengan materi yang akan dipelajari, namun hanya beberapa siswa yang rasa ingin tahunya tinggi. Selanjutnya tahap Problem statement siswa dilatih menggunakan kemampuan berpikir lancar (fluency) yang terlihat pada aktivitas guru membimbing siswa merumuskan masalah tentang pengertian pencemaran, jenis pencemaran dan penyebab pencemaran lingkungan dilanjutkan dengan membuat gagasan berupa hipotesis mengenai rumusan masalah yang telah dibuat dan menuangkannya pada LKS yang dibuat guru. Hal ini sesuai dengan pendapat Vassiliki Deri dan Maria Pachta (2007) yang menyatakan bahwa penggunaan pertanyaan dapat membentu siswa mengoptimalkan proses berpikirnya tetapi dengaan pertanyaan yang berbeda. Tahapan selanjutnya Data collecting, melatih kemampuan berpikir elaboration yaitu guru membimbing siswa mencari pengertian pencemaran, jenis- jenis pencemaran dan faktor - faktor yang mempengaruhi pencemaran melalui kegiatan pengamatan di luar kelas. Siswa melakukan pengamatan lingkungan di luar kelas meliputi kantin belakang sekolah, kebun belakang sekolah, jalan raya dekat sekolah, halaman, selokan, dan lingkungan sekitar sekolah lainnya. Pelaksanaan pengamatan di luar sekolah berjalan lancar karena siswa melakukan kegiatan sesuai alokasi waktu dan semua anak terlibat aktif. Siswa sangat antusias dan bersemangat melakukan pengamatan di lingkungan sekolah sehingga tercipta interaksi antar teman sekelompok dan antar siswa dengan guru. Kemudian pada Data processing, rangkaian kegiatan yang dilakukan siswa adalah untuk melatih kemampuan berpikir originality. Pada pertemuan pertama ini guru membimbing siswa menuliskan apa yang telah mereka dapat dari pengamatan pencemaran di lingkungan sekolah dan mendiskusikan dengan teman sekelompok sehingga didapatkan kesimpulan kelompok masing-masing. Pada kegiatan ini semua anggota kelompok berperan aktif menuangkan aspirasinya mengenai lingkungan yang mereka amati.

Tahapan selanjutnya Verification yaitu guru membimbing siswa menarik kesimpulan kelompoknya masing - masing kemudian mempresentasikan di kelas. Pelaksanaan kegiatan diskusi kelas ini siswa mempresentasikan hasil kesimpulan kelompoknya. Suasana kelas terlihat hidup dengan adanya interaksi antar kelompok yang saling melontarkan pertanyaan, jawaban maupun pendapat kelompok masing-masing. Tahap yang terakhir adalah Generalization dimana siswa dan guru bersama- sama membuat kesimpulan umum dari diskusi kelas. Selama pembelajaran berlangsung siswa aktif bertanya dan menyampaikan gagasan untuk menemukan pemecahan permasalahan materi pencemaran lingkungan,sehingga saat guru mengajukan pertanyaan siswa tidak kesulitan untuk menjawab.

Pada pertemuan kedua dimulai dengan stimulation yaitu guru memberi rangsangan melalui alat dan bahan yang dibawa siswa dari rumah seperti cacing, ikan dan daun yang diambil dari taman sekolah kemudian siswa diminta mengamatinya selanjutnya diberi pertantaan yang ingin mereka ketahui dan pelajari. Pada pertemuan ini juga siswa sangat antusias dan memiliki rasa ingin tahu lebih dalam. Tahap stimulation rangsangan yang diberikan guru terbukti dapat melatih kemampuan berpikir kreatif siswa yang terlihat saat siswa dapat memberikan macam-macam penafsiran terhadap suatu gabar, cerita atau masalah (flexibility). Hal tersebut sesuai dengan gagasan Rustaman 
(2005) bahwa pertanyaan yang diberikan guru kepada siswa dapat mendorong melatih kemampuan berpikir sehingga mampu menemukan konsep. Selanjutnya tahap Problem statement siswa dilatih menggunakan kemampuan berpikir lancar (fluency) yang terlihat pada aktivitas guru membimbing siswa merumuskan masalah tentang penyebab pencemaran lingkungan air, tanah, udara terhadap kelangsungan hidup organisme di sekitarnya dilanjutkan dengan membuat gagasan berupa hipotesis mengenai rumusan masalah yang telah dibuat dan menulisnya di LKS yang dibuat guru.

Tahapan selanjutnya Data collecting, melatih kemampuan berpikir elaboration melalui kegiatan siswa yaitu membuat rancangan eksperimen tentang dampak pencemaran terhadap organisme. Sebagian besar siswa bersemangat karena dibebaskan membuat rancangan eksperimen sesuai kreativitasnya. Hal ini sesuai dengan pendapat Widhiantoro (2012) yang menyatakan bahwa Data collecting dapat mengoptimalkan kemampuan berpikir kreatif yaitu berpikir terperinci (elaboration). Kemudian pada Data processing, rangkaian kegiatan yang dilakukan siswa adalah untuk melatih kemampuan berpikir originality melalui kegiatan eksperimen pengaruh pencemaran terhadap organisme meliputi praktikum pencemaran air dengan sumber belajar beberapa sampel ikan yang dibawa siswa dari yang diberi perlakuan sesuai rancangan siswa, kemudian praktikum pencemaran tanah dengan sumber belajar cacing yang didapat dari lingkungan rumah siswa dan praktikum pencemaran udara dengan mengamati sampel tumbuhan yang diambil dari taman sekolah. Balim (2009) menyatakan bahwa metode pembelajaran penemuan mengharuskan siswa menganaliais konsep, informasi dengan membahas pertanyaan untuk mendapat informasi sendiri. Kegiatan eksperimen pengaruh pencemaran terhadap organisme pada pertemuan kedua ini berjalan lancar karena siswa telah memahami prosedur eksperimen. Siswa juga terlihat senang karena tidak hanya belajar teori melainkan langsung mempraktekan sendiri mengenai materi dampak pencemaran dan mengetahui polutan yang mencemari lingkungan.

Setelah melakukan kegiatan eksperimen siswa diajak melakukan tahapan Verification yaitu siswa dibimbing menarik kesimpulan kelompoknya masing - masing sesuai dengan praktikum yang di praktekan siswa kemudian kesimpulan kelompok tersebut dipresentasikan di kelas. Pada saat kegiatan presentasi ini semua kelompok penyaji mendapatkan pertanyaan dari kelompok lain. Tiap kelompok yang mendapatkan pertanyaan memiliki cara masing-masing untuk menjawab, ada yang melalui lisan ada pula yang melalui lisan dan gambar di papan tulis sehingga kegiatan presentasi terlihat hidup. Setelah semua kelompok mempresentasikan hasil diskusinya masuklah ke tahap yang terakhir yaitu Generalization dimana siswa dan guru bersama- sama membuat kesimpulan umum dari diskusi kelas.

Selanjutnya, pada pertemuan ketiga siswa hanya melakukan tahapan Verification dan Generalization saja karena tahapan stimulation, problem statement, data collection, data processing telah dilaksanakan sebagai tugas rumah yaitu mencari upaya pelestarian lingkungan yang ada di sekitar rumah siswa. Data yang didapatkan oleh siswa dikaitkan dengan sumber yang ada bisa dari buku atau internet kemudian menyusunnya sebagai makalah dan dipresentasikan pada pertemuan ketiga. Pada tahap Verification tiap kelompok mempresentasikan hasil kerjanya dirumah dan kelompok lainnya menanggapi. Ketika diskusi kelas ini kelompok penyaji tidak hanya mendapatkan beberapa pertanyaan dari kelompok lain, melainkan mendapatkan tambahan informasi sehingga antar kelompok dapat saling melengkapi kekurangannya masing-masing. Setelah kegiatan diskusi kelas selesai dilanjutkan dengan Generalization dimana siswa dan guru bersama- sama membuat kesimpulan umum dari diskusi kelas mengenai upaya pelestarian lingkungan. Diakhir kegiatan siswa dan guru bersama-sama mengulas ulang materi dan melakukan beberapa tanya jawab. Siswa yang belum memahami materi diberi kesempatan bertanya. Setelah sudah tidak ada pertanyaan, kegiatan pembelajaran ditutup dengan post test.

Perbedaan proses pembelajaran kelas kontrol dan eksperimen yaitu di kelas eksperimen siswa yang aktif lebih banyak dibandingkan pada kelas kontrol. Hal ini dikarenakan siswa dikelas kontrol kurang antusias dan cenderung cepat bosan karena kegiatan pembelajaran hanya berkutat di dalam kelas dan hanya bersumber dari buku maupun internet sedangkan pada kelas eksperimen pembalajaran dilakukan di kelas, laboratorium, lingkungan sekolah dan lingkungan rumah siswa. Sumber belajar yang digunakan lebih nyata dan beragam karena diambil dari lingkungan sekitar. Kegiatan pembelajaran di kelas eksperimen juga melibatkan siswa langsung dalam praktikum dan membebaskan siswa merancang sendiri eksperimen yang mereka akan lakukan dengan bimbingan dari guru. Sedangkan pada kelas kontrol hanya menggunakan diskusi kelompok dengan mencari informasi dari buku dan internet tidak mempraktekan secara langsung, sehingga ada beberapa siswa yang diam dan kurang aktif menyampaikan aspirasinya dalam diskusi kelompok.

Berdasarkan hasil analisis penelitian ini menunjukkan bahwa dalam pembelajaran biologi menggunakan model pembelajaran Guided Discovery berbasis lingkungan dapat melatih siswa dalam mengembangkan kemampuan berpikir kreatif karena dalam. Peningkatan terjadi karena siswa terlibat langsung dan aktif dalam proses pembelajaran serta memecahkan masalah dengan cara investigasi langsung dibantu dengan sumber belajar lingkungan.

\section{KESIMPULAN}

Berdasarkan hasil penelitian tentang model pembelajaran Guided Discovery berbasis lingkungan terhadap kemampuan berpikir kreatif siswa kelas X SMA Negeri 1 Sukoharjo dapat disimpulkan bahwa ada pengaruh antara model pembelajaran Guided Discovery berbasis lingkungan dengan model pembelajaran konvensional 
terhadap kemampuan berpikir kreatif biologi siswa kelas X SMA Negeri 1 Sukoharjo.

\section{DAFTAR PUSTAKA}

Balim,A. G. (2009). The Effect Of Discovery Learning on Student's Success and InquiryLearning Skills. Egitim Arastirmalari-Eursian Journal of Education Reaserch, $35,1-20$

Munandar, U. (2004). Pengembangan Kreativitas Anak Berbakat. Jakarta: PT Rineka Cipta.

Rustaman, N.2005. Strategi Belajar Mengajar Biologi. Malang: UM press

Rohim, Fathur., Hadi Susanto., Ellianawati. 2012. Penerapan Model Discovery Terbimbing Pada Pembelajarn Fisika Untuk Meningkatkan Kemampuan Berpikir Kreatif. Unnes Physics Education Journal 1 (1) ISSN NO 2257-6935

Syamsudduha, S., \& Rapi, M. (Juni 2012). Penggunaan Lingkungan Sekolah SebagaiI Sumber Belajar Dalam Meningkatkan Hasil Belajar Biologi. Lentera Pendidikan, VOL. 15 NO. 1 JUNI 2012: 18-31, VOL. 15 NO. 1 18-31.

Vassiliki Derri \& Maria Pachta. 2007. Motor skills and concept sacquistion and retention: a comparation between two styles of teaching. International Journal of Sport Science Volume III:37-47 ISSN: 1885-3137

Widhiyantoro, T. (September 2012). The Effectiveness Of Guided Discovery Method. Pendidikan Biologi, Vol 4, No 3, 89-99. 